\title{
FAKTOR-FAKTOR YANG MEMPENGARUHI RETURN SAHAM PADA SEKTOR PERBANKAN YANG GO PUBLIK DI BURSA EFEK INDONESIA
}

\author{
Esli Silalahi' ${ }^{1}$, Evelin Roma Riauli Silalahi ${ }^{2}$ \\ ${ }^{1,2}$ Fakultas Ekonomi Program Studi Akuntansi Universitas Katolik Santo Thomas \\ esli2silalahi@gmail.com ${ }^{1}$ \\ $\underline{\text { evelinsilalahi37@gmail.com }}^{2}$
}

\begin{abstract}
ABSTRAK
Tujuan penelitian ini untuk menguji secara empiris Faktor-Faktor Yang Mempengaruhi Return saham Pada Sektor Perbankan Yang Go Publik Di Bursa Efek Indonesia. Metode pengumpulan data yang digunakan adalah tehnik dokumentasi dengan memperoleh data laporan keuangan perusahaan, yang dapat diakses melalui www.idx.co.id. Metode analisis yang digunakan adalah analisis regresi linear berganda, dengan melakukan uji asumsi klasik yaitu: uji normalitas, uji multikolonieritas dan uji heteroskedastisitas, kemudian melakukan uji t dan uji $\mathrm{F}$ untuk menguji secara empiris Faktor-Faktor Yang Mempengaruhi Return saham Pada Sektor Perbankan Yang Go Publik Di Bursa Efek Indonesia secara parsial dan simultan. Populasi dalam penelitian ini adalah sektor perbankan periode pengamatan tahun 2015- 2018, sebanyak 43 perusahaan perbankan, dengan jumlah sampel sebanyak 24 perusahaan perbankan dimana penentuan sampel dengan purposive sampling yaitu berdasarkan kriteria yang ditentukan. Hasil penelitian menunjukkan bahwa Likuiditas (LQ), Price Earning Ratio (PER), Debt to Equity Ratio (DER), Earning Per share (EPS) berpengaruh secara parsial dan signifikan terhadap return saham; Likuiditas (QR), Price Earning Ratio (PER), Debt to Equity Ratio (DER), Earning Per share (EPS) berpengaruh secara simultan dan signifikan terhadap return saham.
\end{abstract}

Kata Kunci : Likuiditas (LQ), Price Earning Ratio (PER), Debt to Equity Ratio (DER), Earning Per share (EPS) dan return Saham

\section{Latar Belakang}

Perbankan merupakan suatu lembaga keuangan yang memegang peranan yang sangat penting dalam masyarakat. Khususnya dalam segi perekonomian, bank bukan sekedar sumber dana bagi pihak yang memiliki kelebihan dana, tetapi juga memiliki fungsi-fungsi lain yang semakin meluas dari waktu ke waktu. Lembaga keuangan seperti bank membutuhkan dana eksternal untuk mengekspansi usahanya. Ketika dana internal seperti laba yang ditahan tidak cukup untuk melakukan ekspansi, maka bank juga akan membutuhkan dana eksternal dari investor dipasar modal. 
Peraturan Bank Indonesia Nomor 16/11/PBI/2014 tentang Pengaturan dan Pengawasan Makroprudensial, secara umum membahas bahwa krisis keuangan global menimbulkan dampak yang negatif terhadap sektor keuangan bahkan kinerja makroekonomi menimbulkan biaya pemulihan ekonomi yang tinggi. Stabilitas sistem keuangan yang terjaga menjadi sangat penting mengingat besarnya dampak yang diberikan oleh kondisi krisis keuangan global bahkan oleh resiko sistemik yang mungkin ditimbulkan dalam sistem keuangan Negara. Pengaturan dan pengawasan Makroprudensial diperlukan untuk mencegah serta mengurangi resiko sistemik, mendorong fungsi intermediasi yang seimbang dan berkualitas, serta meningkatkan efisiensi dari sistem keuangan dan akses keuangan.

Statistik Perbankan Indonesia periode Oktober 2015 yang diterbitkan OJK menunjukkan rasio NPL(non performing loan) perbankan nasional meningkat. Pada Oktober 2015, NPL bank tercatat sebesar 2,67\% atau naik 33 basis poin secara tahunan (year-on-year) dari 2,34\%. Peningkatan NPL itu sejalan dengan perlambatan penyaluran kredit perbankan yang tumbuh sebesar 10,26\% dari Oktober 2014 senilai Rp3.558,07 triliun menjadi Rp3.923,43 triliun. (Bisnis.com, JAKARTA 2015). Faktor perlambatan perekonomian domestik, pertumbuhan kredit yang kembali melambat juga terjadi karena adanya pengaruh write off yang dilakukan bank-bank serta penjualan aset beberapa bank ke grup terkait. Argumen ini yang menyebabkan penelitian sektor perbankan penting untuk dilakukan.

Investor maupun calon investor dapat memperkirakan berapa tingkat pengembalian yang diharapkan (expected return) dan seberapa jauh kemungkinan hasil yang sebenarnya nanti akan menyimpang dari hasil yang diharapkan. Apabila kesempatan investasi mempunyai tingkat risiko yang lebih tinggi, maka investor akan mengisyaratkan tingkat keuntungan yang lebih tinggi pula. Dengan kata lain, semakin tinggi risiko suatu kesempatan investasi maka akan semakin tinggi pula tingkat keuntungan (return) yang diisyaratkan oleh oleh investor (Jogiyanto, 2000).

Return saham adalah tingkat keuntungan yang dinikmati oleh pemodal atas suatu investasi yang dilakukannya (Robert Ang, 2001). Dalam teori pasar modal, tingkat pengembalian yang diterima oleh seorang investor dari saham yang diperdagangkan di pasar modal biasa diistilahkan dengan return. Return dapat berupa return realisasi yang sudah terjadi atau return ekspektasi yang belum terjadi tetapi yang diharapkan akan terjadi di masa mendatang. Return realisasi (realized return) merupakan return yang telah terjadi dan di hitung berdasarkan data histori 
dan return realisasi digunakan sebagai salah satu pengukur kinerja dari perusahaan sebagai dasar penentu return ekspektasi (expected return) dan resiko di masa mendatang.

Return saham dapat dipengaruhi oleh faktor fundamental dan faktor atau variabel makro ekonomi. Terdapat banyak indikator yang dapat mengukur variabel makro secara teori termasuk didalamnya indikator politik ekonomi. Indikator yang cukup lazim digunakan untuk memprediksi fluktuasi saham adalah variabel yang secara langsung dikendalikan melalui kebijakan moneter dengan mekanisme transmisi melalui pasar keuangan

Faktor fundamental adalah faktor faktor yang berasal dari dalam perusahaan dimana faktor fundamental ini bisa dilihat dari laporan keuangan, dan dari laporan keuangan emiten mencerminkan tingkat kinerja keuangan perusahaan, apakah kinerja dalam kondisi yang baik atau sebaliknya. Kinerja yang baik cenderung meningkatkan harga saham dan dengan sendirinya dapat meningkatkan return yang diterima investor. Hal ini di sebabkan kepercayaan investor kepada emiten semakin baik, investor mempunyai harapan akan memperoleh bagian keuntungan atau dividen yang besar.

Sudiyatno dan Irsad (2011) menyatakan bahwa banyak faktor yang mempengaruhi return saham, diantaranya adalah informasi yang bersifat fundamental maupun teknikal. Penggunaan model menjadi sangat penting untuk menilai harga saham dan membantu investor dalam merencanakan dan memutuskan investasi mereka secara efektif.

Beberapa penelitian tentang faktor-faktor yang mempengaruhi return saham yang berhubungan dengan rasio keuangan perusahaan telah dilakukan oleh beberapa peneliti sebelumnya diantaranya adalah $\mathrm{Ou}$ \& Penman (89) dalam Ulupui (2009) meneliti manfaat laporan keuangan dalam memprediksi return saham. Hasil penelitian menunjukkan bahwa informasi akuntansi mengandung informasi fundamental yang tidak tercermin dalam harga saham. Dyah Kumala Trisnaeni dalam (Farkhan Ika, 2013) meneliti pengaruh kinerja keuangan meliputi rasio leverage, rasio profitabilitas dan rasio pasar terhadap return saham, Hasil penelitian menunjukkan rasio leverage dan rasio profitabilitas mempunyai pengaruh yang negatif terhadap return saham, sedangkan rasio pasar berpengaruh positif terhadap return saham.

Penelitian tentang pengaruh debt to equity ratio, pertumbuhan earning pershare, dividend yield, price earning ratio dan pertumbuhan indeks harga saharn gabungan terhadap terhadap return saham yang 
dilakukan Achmad dalam Suparno (2002). Hasil penelitian menunjukkan faktor-faktor debt to equity ratio, pertumbuhan earning pershare, dividend yield, price earning ratio dan pertumbuhan indeks harga saham gabungan berpengaruh terhadap return saham baik secara sirnultan dan parsial

Penelitian yang sama juga dilakukan oleh Nurul dalam Rahayu (2003) hasil penelitian menunjukkan terdapat korelasi negatif antara price earning ratio (PER) dengan return sahan dan PER berpengaruh signifikan terhadap return saham.

Yogo Purnomo dalam (Manao dan Deswin 2001), menganalisis lima rasio keuangan terdiri dari total debt to equity ratio (DER), return on equity (ROE), earning per share (EPS), price eraning ratio (PER) dan devidend per share (DPS) serta melihat hubungannya dengan harga saham. Hasil penelitian menunjukkan return on equity $(R O E)$, earning per share (EPS), price eraning ratio (PER) dan devidend per share (DPS) berpengaruh signifikan sedangkan debt to equity ratio (DER) tidak berpengaruh signifikan terhadap perubahan kurs.

Penelitian dari sektor makroekonmi yang dilakukan Durham, (2000) hasil penelitian menunjukkan terdapat pengaruh perubahan tingkat suku bunga jangka pendek pada Return saham. Perubahan kebijakan moneter akan mempengaruhi pasar modal melalui perubahan yang terjadi pada pengeluaran konsumsi dan investasi. Penurunan pada tingkat suku bunga akan mendorong pengeluaran konsumsi dan investasi yang selanjutnya akan meningkatkan harga saham termasuk return saham.

Noviandari (2007) menujukkan bahwa variabel nilai tukar Rupiah terhadap US Dollar dan inflasi secara parsial tidak memiliki korelasi dengan Indeks harga saham sektor keuangan, variabel tingkat suku bunga berpengaruh terhadap pergerakan IHSS Keuangan, nilai tukar rupiah terhadap US Dollar dan tingkat suku bunga secara simultan berpengaruh terhadap IHSS Keuangan, sementara tingkat inflasi tidak memberikan pengaruh terhadap pergerakan IHSS Keuangan

Berdasarkan hasil penelitian sebelumnya terhadap industri atau kelompok perusahaan yang berbeda serta teori yang mendasari, menunjukkan masih adanya research gap faktor-faktor yang mempengaruhi return saham. Dalam Penelitian ini menyoroti faktor-faktor yang mempengaruhi return saham sektor perbankan khususnya faktor fundamental perusahaan. 


\section{A. Perumusan Masalah}

1. Apakah Likuiditas ( $L Q)$, Price Earning Ratio (PER), Debt to equity Ratio (DER), dan Earning Pershare (EPS) berpengaruh secara simultan terhadap return saham pada sektor perbankan di Bursa Efek Indonesia

2. Apakah Likuiditas (LQ), Price Earning Ratio (PER), Debt to equity Ratio (DER), dan Earning Pershare (EPS) berpengaruh secara parsial terhadap return saham pada sektor perbankan di Bursa Efek Indonesia

3. Variabel mana yang lebih dominan mempengaruhi return saham pada sektor perbankan Yang Go Publik di Bursa Efek Indonesia

\section{B. Tinjauan Pustaka \\ Theory Signalling}

Teori Sinyal menjelaskan tentang bagaimana para investor memiliki informasi yang sama tentang prospek perusahaan. Teori signaling dikembangkan dalam ilmu ekonomi dan keuangan untuk memperhitungkan kenyataan bahwa orang dalam (insiders) perusahaan pada umumnya memiliki informasi yang lebih baik dan lebih cepat berkaitan dengan kondisi mutakhir dan prospek perusahaan dibandingkan dengan investor luar. Teori ini menjelaskan bahwa laporan keuangan yang baik merupakan sinyal atau tanda bahwa perusahaan juga telah beroperasi dengan baik.

Menurut Sunardi (2010) informasi yang dipublikasikan sebagai suatu pengumuman akan memberikan signal bagi investor dalam pengambilan keputusan investasi. Jika pengumuman tersebut mengandung nilai positif, maka pasar akan bereaksi baik dengan pihak lain. Reaksi pasar ditunjukkan dengan adanya perubahan volume perdagangan saham. Pada waktu informasi diumumkan dan semua pelaku pasar sudah menerima informasi tersebut, pelaku pasar terlebih dahulu menginterpretasikan dan menganalisis informasi tersebut sebagai signal baik bagi investor, maka terjadi perubahan dalam volume perdagangan saham.

Teori Sinyal juga mengemukakan tentang bagaimana seharusnya sebuah perusahaan memberikan sinyal kepada pengguna laporan keuangan. Sinyal tersebut berupa informasi mengenai kondisi perusahaan kepada pemilik ataupun pihak yangberkepentingan. Sinyal yang diberikan dapat juga dilakukan melalui pengungkapan informasi akuntansi seperti laporan keuangan atau dapat berupa promosi serta informasi lain yang 
menyatakan bahwa perusahaan tersebut lebih baik dari pada perusahaan lain.

Salah satu cara melakukan analisis investasi dalam bentuk saham adalah dengan analisis fundamental. Analisis fundamental menyatakan bahwa setiap investasi saham mempunyai landasan yang kuat yang disebut dengan nilai instrinsik yang dapat ditentukan melalui suatu analisis terhadap kondisi perusahaan pada saat sekarang dan prospeknya di masa mendatang. Nilai instrinsik merupakan suatu fungsi dari faktor-faktor perusahaan yang dikombinasikan untuk menghasilkan suatu keuntungan yang diharapkan dengan suatu risiko yang melekat pada saham tersebut. Faktor fundamental perusahaan adalah faktor yang mencerminkan atau mempengaruhi kinerja perusahaan dalam bentuk indikator finansial. Faktor fundamental perusahaan yang digunakan memproyeksi return saham adalah dilihat dari laporan keuangan melalui rasio keuangan meliputi kemampuan perusahaan dalam membayar hutang jangka pendek yg segera jatuh tempo, Likuiditas (LQ); ratio nilai pasar, Price Earning Ratio (PER); kemampuan membayar hutang (solvabilitas),Debt to equity Ratio (DER); kemampuan perusahaan dalam menghasilkan laba, (Profitabilitas) dan rasio nilai pasardan Earning Pershare (EPS)

Likuiditas kemampuan perusahaan perbankan dalam memenuhi kewajiban dan kemampuan membayar kembali simpanan nasabah dimana likuiditas diukur dari quick ratio.

$$
L Q=\frac{\text { Cash Assets }}{\text { Total Deposit }} \times 100 \%
$$

Debt to equity ratio (DER) mengukur seberapa besar perusahaan menggunakan hutang dalam struktur modalnya dan juga mencerminkan kemampuan perusahaan dalam memenuhi seluruh kewajibannya.

$$
\text { DER }=\frac{T \text { otal Debt }}{\text { Total Equity }} \times 100 \% \text {. }
$$

Price earning ratio (PER) menggambarkan apresiasi pasar terhadap kemampuan perusahaan dalam menghasilkan laba, yaitu perbandingan harga saham dengan laba per lembar saham.

$$
P E R=\frac{\text { Market price per share }}{\text { Earning per share }}
$$

Earning Per share (EPS) adalah menunjukkan jumlah rupiah yang akan diperoleh untuk setiap lembar saham.

$$
E P S=\frac{\text { Earning Available to common share holders }}{\text { Number of share common stock outstanding }}
$$




\section{Return Saham}

Return merupakan hasil yang diperoleh dari suatu investasi. Menurut Jogiyanto (2000), return saham dibedakan menjadi dua yaitu return realisasi (realized return) dan return ekspektasi (expected return). Return realisasi merupakan return yang sudah terjadi yang dihitung berdasarkan data historis. Return realisasi ini penting dalam mengukur kinerja perusahaan dan sebagai dasar penentuan return dan risiko dimasa mendatang. Return saham yaitu merupakan penghasilan yang diperoleh investor atas investasi yang ditanamkan dalam bentuk saham, dimana return saham dapat diukur sebagai berikut :

$$
\begin{aligned}
& R t S=\frac{D_{t}+\left(P_{t}-P_{t-1}\right)}{P_{t-1}} . \\
& R_{t S}=\text { Return saham } \\
& P_{i t}=\text { Harga saham penutupan ke } \mathrm{i} \text { pada periode } \mathrm{t} \\
& P_{\text {it }-1}=\text { Harga saham penutupan ke i pada periode } \mathrm{t}-1 \\
& \mathrm{Dt}=\text { Deviden pada periode } \mathrm{t}
\end{aligned}
$$

\section{Pengaruh likuiditas terhadap return saham}

Likuiditas adalah rasio yang digunakan untuk mengukur bagaimana kemampuan perusahaan dalam hal ini perbankan dalam memenuhi kewajiban hutang, kemampuan membayar kembali simpanan nasabah serta dapat memenuhi permintaan kredit yang diajukan tanpa agunan. Aristanto (2002). Fungsi likuiditas bagi bank adalah bagaimana kemampuan bank dalam membayar seluruh kewajibannya bagi deposan, sehingga bank dapat meneruskan kegiatannya, hal ini dapat meningkatkan return saham.

Likuiditas adalah kemampuan perusahaan dalam membayar kewajiban jangka pendek yang segera jatuh tempo. Likuiditas diukur dengan Curent ratio merupakan indikator jangka pendek terhadap kemampuan perusahaan untuk membayar kewajiban-kewajiban jangka pendeknya dengan menggunakan aktiva lancar yang tersedia (Syamsyudin,2007). Dengan kata lain, seberapa besar aktiva lancar yang tersedia mampu menutupi dengan segera kewajiban lancarnya. Selain current ratio likuiditas juga diukur dari quick ratio. Curent ratio yang semakin tinggi menunjukkan semakin besar kemampuan perusahaan untuk memenuhi kewajiban finansial jangka pendeknya. Meythi (2006) membuktikan bahwa likuiditas yang dapat memprediksi return saham perusahaan manufaktur. Hasil serupa juga di peroleh dari hasil penelitian Wiksuana (2008). Sebaliknya, Wira (2008) menyatakan bahwa likuiditas tidak mempunyai pengaruh terhadap return saham. 


\section{Pengaruh price earning ratio (PER) terhadap return saham.}

Price earning ratio (PER)) adalah rasio yang dipergunakan untuk mengukur nilai pasar yang menghubungkan harga saham perusahaan dengan labanya. PER merupakan salah satu variabel yang dipertimbangkan oleh investor dalam menentukan saham mana yang akan dibeli, karena PER mengindikasikan kepada masyarakat dan pihak investor pada khususnya tentang prestasi dan prospek perusahaan yang bersangkutan.

Bagi investor membeli saham berarti membeli prospek perusahaan, oleh karena itu perusahaan yang mempunyai prospek yang bagus akan mendorong investor untuk membeli saham perusahaan tersebut. Pada umumnya investor percaya bahwa perusahaan dengan PER yang tinggi berarti perusahaan tersebut mempunyai prospek pertumbuhan yang bagus. Perusahaan yang mempunyai PER yang tinggi akan menarik investor untuk membeli saham perusahaan tersebut. PER yang tinggi menunjukkan harga saham dinilai semakin tinggi oleh investor terhadap pendapatan perlembar sahamnya, sehingga PER yang semakin tinggi menunjukkan semakin mahal saham tersebut terhadap pendapatannya. Jika harga saham semakin tinggi maka selisih harga saham periode sekarang dengan periode sebelumnya semakin besar, maka capital gain juga semakin meningkat. Hal ini di sebabkan karena capital gain (actual return) dihitung dari selisih antara harga saham periode sekarang dengan harga saham periode sebelumnya. Berdasarkan konsep tersebut menunjukkan semakin tinggi PER maka return saham juga semakin meningkat, sehingga PER berpengaruh positif dengan return saham.

\section{Pengaruh debt to equity ratio (DER) terhadap return saham}

Debt to equity ratio (DER) adalah rasio yang menunjukkan sampai seberapa besar perusahaan menggunakan hutang dalam struktur modalnya dan juga mencerminkan kemampuan perusahaan dalam memenuhi seluruh kewajibannya. Penggunaan hutang sebagai sumber pendanaan akan menyebabkan perusahaan harus menanggung beban tetap berupa bunga dan cicilan hutang, sehingga peningkatan hutang akan mempengaruhi besar kecilnya pendapatan bersih yang tersedia bagi pemegang saham. Weston dan Brigham (2006) yang menyatakan bahwa jika perusahaan memperoleh tingkat laba yang lebih tinggi atas dana pinjamannya daripada tingkat bunga yang dibayarkan atas dana tersebut, berarti akan dapat meningkatkan kekayaan pemilik modal.

Salah satu sumber modal dari bank adalah tabungan dari para 
nasabah. Tabungan dari para nasabah sendiri pada hakikatnya adalah utang yang diberikan nasabah kepada bank. Tabungan tersebut oleh bank kemudian diputar dan dijadikan modal untuk pergerakan ekonomi bank sendiri untuk menjalankan programnya seperti program pinjaman. Semakin tinggi tabungan para nasabah, justru akan semakin bagus bagi bank. Dengan kata lain, semakin tinggi total utang bank, maka semakin bagus bagi bank. Maka, nilai debt to equity ratio yang tinggi dari bank tidak menandakan bahwa keadaan perekonomian dari bank tersebut buruk, namun bisa juga berarti bagus.

Beberapa bukti empiris mengenai pengaruh DER terhadap return saham juga menunjukkan hasil yang berbeda. Penelitian yang dilakukan oleh Damodaran, 1997 (dalam Suparto, 2000) menyatakan bahwa alternatif test hypothesa optimal capital structure adalah untuk menguji reaksi harga saham terhadap tindakan yang diambil perusahaan baik menaikkan atau menurunkan leverage-nya. Dalam mencapai optimal leverage, secara rasional akan mempunyai dampak positif excess return, yang selanjutnya menaikkan harga saham. Jika sudah optimal leverage, hubungan leverage dengan harga saham berbentuk kurva. Karena excess return berkaitan dengan naiknya harga saham sebelum dan sesudah pengumuman capital structure, sehingga dapat dikatakan bahwa financial leverage mempunyai pengaruh positif terhadap harga saham yang akhirnya mempengaruhi return saham. Hasil penelitian tersebut berpengaruh positif dan signifikan terhadap perubahan harga saham. Namun penelitian yang dilakukan oleh Gordon yang diulas oleh Bolten, 1976 (Ika Rahayu, 2003) menunjukkan DER mempunyai pengaruh yang negatif terhadap harga saham.

Penelitian sejenis yang dilakukan oleh Santoso dalam Ika Rahayu (2003), menyimpulkan bahwa variabel DER tidak berpengaruh signifikan terhadap perubahan harga saham. Hasil penelitian tersebut konsisten dengan penelitian Sparta (2000) dan Purnomo dalam Ika Rahayu (2003) yang menunjukkan bahwa DER tidak berpengaruh signifikan untuk menerangkan perubahan harga saham dan tidak dapat dijadikan pertimbangan satu-satunya bagi pemodal atau investor untuk memproyeksikan harga saham di masa depan. Hasil penelitian Mulyono dan Khairurizka (dalam Sudiyatno 2016) menyatakan bahwa DER tidak berpengaruh terhadap return saham. 


\section{Pengaruh earning pershare (EPS) terhadap retur saham}

Earning per share (EPS) dari suatu perusahaan dapat ditentukan dengan cara rnembandingkan antara laba bersih setelah pajak dan jumlah lembar saham biasa yang beredar. Besar kecilnya earning per share sangat bergantung pada laba bersih perusahaan setelah pajak dan jumlah lembar saham biasa yang beredar. Rasio ini merupakan suatu indikator yang sangat berpengaruh terhadap harga saham, karena investor percaya bahwa nilai sualu saham akan tergantung pada kemampuan perusahaan dalam menghasilkan earning untuk tiap lembar sahamnya,.Pengertian earning yang terkait dalam earning per share menunjukkan kemampuan perusahaan dalam meraih keuntungan dalam menjalankan operasi perusahaan. Perusahaan yang menghasilkan earning yang tinggi tentu saja akan disukai oleh investor karena dividen akan dibagikan apabila perusahaan memperoleh keuntungan.

Bagi para investor, informasi EPS merupakan informasi yang dianggap paling mendasar dan berguna, karena bisa menggambarkan prospek earnings diperusahaan masa depan (Tandelilin,2010). Kenaikan EPS berarti perusahaan sedang dalam tahap pertumbuhan atau kondisi keuangannya sedang mengalami peningkatan dalam penjualan dan laba. Apabila EPS suatu perusahaan tinggi ini akan meningkatkan investor untuk membeli dan menawar saham yang mengakibatkan harga saham akan tinggi, EPS yang tinggi menandakan kemampuan perusahaan dalam menghasilkan keuntungan bersih setiap lembar saham juga tinggi yang akan berpengaruh terhadap return yang diperoleh investor, EPS berpengaruh terhadap return saham,Hanafi dalam Arian Absari,D.Y. (2012)

\section{Metodologi Penelitian \\ Populasi dan Sampel}

Populasi dalam penelitian ini adalah seluruh sektor perbankan yang go publik di Bursa Efek Indonesia pada tahun 2015-2018, sebanyak 43 perusahaan perbankan, sampel penelitian sebanyak 24 perusahaan perbankan dimana penarikan sampel dengan metode purposive sampling penanarikan sampel berdasarkan kriteria, maksud dan tujuan penelitian. Kriteria sampel adalah sebagai berikut : (1). Perusahaan yang dipilih adalah perusahaan perbankan yang telah go pulik di Bursa Efek Indonesia selama periode pengamatan yang sahamnya aktif diperdagangkan di BEI; (2). Perusahaan perbankan yang telah menerbitkan laporan keuangan yang lengkap yang telah diaudit pada selama periode pengamatan; (3). 
Perusahaan perbankan yang memberikan return saham yang positif sepanjang periode pengamatan

\section{Metode Pengumpulan Data}

Metode pengumpulan data yang digunakan dalam penelitian ini adalah tehnik Dokumentasi melalui data laporan keuangan perbankan yang dapat diakses melalui www.idx.co.id.

\section{Operasionalisasi variabel}

Variabel dependent adalah return saham (RtS) meupakan suatu penghasilan yang diperoleh investor atas investasi yang ditanamkan dalam bentuk saham.

RtS = Return Saham

$$
\text { RtS }=\frac{D_{t}+\left(P_{t}-P_{t-1}\right)}{P_{t-1}}
$$

$D_{t}=$ Devidend yang dibayarkan pada periode $\mathrm{t}$

$P_{t} \quad=$ Harga saham pada periode $\mathrm{t}$

$P_{t-1}=$ Harga saham pada periode $\mathrm{t}-1$

Variabel independent (LQ, PER, DER, EPS)

Likuiditas adalah kemampuan perbankan dalam memenuhi kewajiban hutang, kewajibannya bagi deposan, kemampuan membayar kembali simpanan nasabah serta dapat memenuhi permintaan kredit yang diajukan, yang dihitung sebagai berikut

$$
L Q=\frac{\text { Cash Assets }}{\text { Total Deposit }}
$$

Price earning ratio (PER) adalah perbandingan harga saham dengan laba per lembar saham, yang dihitung sebagai berikut:

$$
\text { PER }=\frac{\text { Market price per share }}{\text { Earning per share }}
$$

Debt to equity ratio (DER) adalah perbandingan antara total hutang yang dimiliki perusahaan (perbankan) dengan modal sendiri yang dihitung sebagai berikut:

$$
D E R=\frac{\text { Total Debt }}{\text { Total Equity }}
$$

Earning per share (EPS) adalah menunjukkan jumlah rupiah yang akan diperoleh untuk setiap lembar saham, yang dihitung sebagai berikut:

\section{Tehnik analisis}

$$
E P S=\frac{\text { Earning Available to common share holders }}{\text { Number of share common stock outstanding }}
$$

Tehnik analisis data yang digunakan adalah regresi linear berganda dengan model 


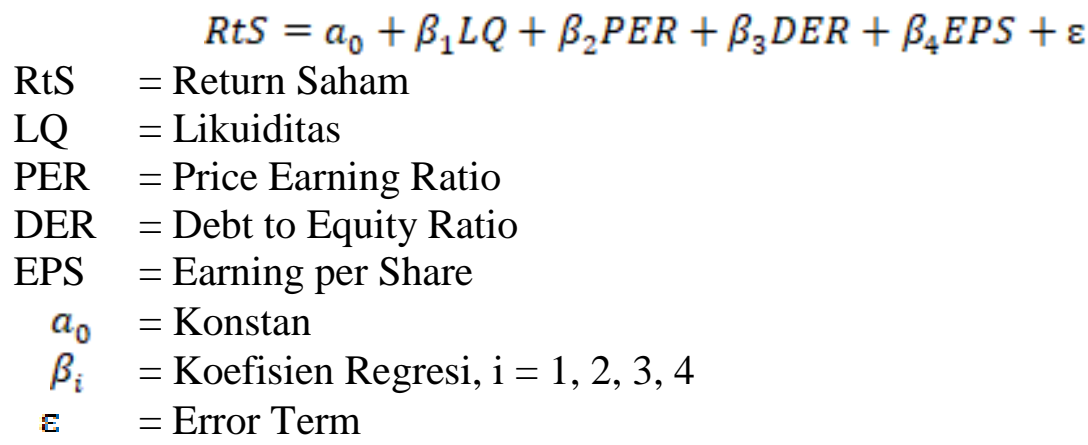

\section{Analisis dan Pembahasan}

Sebelum pengujian hipotesis, dilakukan Uji Asumsi Klasik meliputi normalitas heteroskedastisitas dan multikolinearitasdari. Dari hasil uji asumsi klasik variabel residual terdistribusi secara normal, nilai tolerance masing-masing variabel bebas memiliki nilai variance inflation factor (VIF) kurang dari 0,10 atau tidak ada satupun variabel bebas yang memiliki nilai VIF lebih dari 10, artinya tidak terdapat multikoloniaritas antar variable serta tidak terjadi heteroskedastisitas sehingga model regresi layak digunakan untuk memprediksi return saham berdasarkan masukan keempat variabel independen (likuiditas, PER, DER dan EPS). Tehnik analisis yang digunakan adalah regresi linear berganda dengan hasil penelitian ditunjukkan pada Tabel 1.

Tabel 1 Hasil Analisis Regresi Berganda

\begin{tabular}{|l|c|c|c|c|}
\hline $\begin{array}{c}\text { Variabel Independen } \\
\text { \& Konstan }\end{array}$ & Koefisien regresi & Standard of Error & T hitung & Signifinance \\
& & & & \\
\hline LQ & 0,234 & 0,049 & 4,775 & 0,000 \\
\hline PER & 0,685 & 0,233 & 2,939 & 0,005 \\
\hline DER & 0,188 & 0,050 & 3,760 & 0,001 \\
\hline EPS & 3,677 & 1,608 & 2,287 & 0,000 \\
\hline Constant & $-7,378$ & 1,368 & $-5,393$ & 0,000 \\
\hline R Square & 0,725 & & & \\
\cline { 1 - 2 } Adjusted R Square & 0,525 & & & \\
\cline { 1 - 2 } F. Hitung & 13,001 & &
\end{tabular}




$$
\mathrm{Y}=-7,378+0,234 \mathrm{LQ}+0,685 \mathrm{PER}+0,188 \mathrm{DER}+3,677 \mathrm{EPS}+\mathrm{e}
$$

Dari hasil persamaan tersebut di atas, dapat dijelaskan sebagai berikut:

1. Likuiditas (LQ) mempunyai pengaruh positif terhadap return saham perbankan yang go publik di Bursa Efek Indonesia. Besarnya nilai koefisien regresi sebesar 0,234 artinya apabila likuiditas naik sebesar $1 \%$ maka return saham naik sebesar 0,234. Sebaliknya apabila likuiditas turun sebesar $1 \%$ maka return saham juga turun sebesar 0,234

2. Price Earning Ratio (PER) mempunyai pengaruh positif terhadap return saham perbankan yang go publik di Bursa Efek Indonesia. Besarnya nilai koefisien regresi sebesar 0,685 artinya apabila PER naik sebesar $1 \%$ maka return saham juga akan naik 0,685 . Sebaliknya apabila PER turun sebesar $1 \%$ maka return saham juga akan turun sebesar 0,685

3. Debt to Equity Ratio (DER) mempunyai pengaruh positif terhadap terhadap return saham perbankan yang go publik di Bursa Efek Indonesia.. Besarnya nilai koefisien regresi sebesar 0,188 artinya apabila DER naik sebesar $1 \%$ maka return saham juga akan naik 0,188 . Sebaliknya apabila DER turun sebesar $1 \%$ maka return saham juga akan turun sebesar 0,188

4. Earning Per Share (EPS) mempunyai pengaruh positif terhadap terhadap return saham perbankan yang go publik di Bursa Efek Indonesia. Besarnya nilai koefisien regresi sebesar 3,677 artinya apabila EPS naik sebesar 1\% maka return saham juga akan naik 3,677. Sebaliknya apabila EPS turun sebesar $1 \%$ maka return saham juga akan turun sebesar 3,677

5. Nilai koefisien korelasi mengukur kereratan hubungan antara likuiditas (LQ),Price Earning Ratio (PER),Debt to Equity ratio (DER), dan Earning Per Share (EPS) dengan return saham sebesar 72,5\%. Dari nilai koefisien korelasi tersebut dapat disimpulkan LQ, PER, DER dan EPS mempunyai hubungan yang positif dan kuat dengan return saham.

6. Nilai koefisien determinasi mengukur proporsi variasi return saham dapat dijelaskan proporsi variasi likuiditas (LQ), Price Earning Ratio (PER),Debt to Equity ratio (DER), dan Earning Per Share (EPS. Berdasarkan hasil pengujian di atas besarnya koefisien determinasi adalah 52,5\% artinya bahwa return saham dapat dijelaskan oleh variasi likuiditas (LQ), Price Earning Ratio (PER),Debt to Equity 
ratio (DER), dan Earning Per Share (EPS dan selebihnya sebesar $47,5 \%$ dapat dijelaskan olek faktor lain yang tidak terliput dalam model penelitian ini seperti variabel makroekonomi.

\section{Pengujian Hipotesis}

Dalam penelitian ini pengujian hipotesis yang dilakukan adalah pengujian hipotesis secara parsial (uji t) dan pengujian hipotesis secara simultan (uji F), dan untuk menentukan variabel mana diantara variabel independen yang memiliki pengaruh dominan terhadap variabel dependen. Berdasarkan uji t yang ditunjukkan pada Tabel 1. di atas dapat dijelaskan bahwa Likuiditas (LQ),Price Earning Ratio (PER), Debt to equity Ratio (DER) , dan Earning Pershare (EPS) berpengaruh positif dan signifikan terhadap return saham sektor perbankan yang go di Bursa Efek Indonesia, hal ini ditunjukkan dari nilai signifikan $<0,05$ atau $\mathrm{t}$ hitung $>\mathrm{t}$. table dari masing-masing variable.

Pengujian secara simultan: likuiditas (LQ), Price Earning Ratio (PER),Debt to Equity ratio (DER), dan Earning Per Share (EPS) secara simultan berpengaruh signifikan terhadap return saham sektor perbankan yang go di Bursa Efek Indonesia yang ditunjukkan $\mathrm{F}$ hitung $>\mathrm{F}$ table.

\section{Pembahasan}

Berdasarkan hasil perhitungan yang ditunjukkan Tabel 1. likuiditas (LQ), berpengaruh positif terhadap return saham, besarnya pengaruh likuiditas (LQ) terhadap return saham adalah sebesar 0,234 artinya apabila likuiditas naik sebesar 1 persen maka return saham perbankan naik sebesar 0,234 persen begitu juga sebaliknya, hal ini ditunjukkan nilai arah koefisien regresi. Likuiditas berpengaruh signifikan terhadap return saham dapat dilihat dari nilai signifikan sebesar 0,000 selain itu ditunjukkan dari nilai t hitung > lebih besar dari t table $(4,775>$ 1,960), hal ini sejalan dengan hasil penelitian Wiksuana (2008) dan Meythi (2006) membuktikan bahwa likuiditas dapat memprediksi return saham perusahaan

Price Earning Ratio (PER) berpengaruh positif terhadap return saham. Besarnya pengaruh PER terhadap return saham dapat dilihat dari nilai koefisien regresinya 0,685 Ini berarti kenaikan PER sebesar $1 \%$ akan membuat return saham perbankan di pasar modal mengalami kenaikan sebesar 0,685. Begitu pula sebaliknya ketika PER mengalami penurunan maka return saham juga akan mengalami penurunan, hal ini ditunjukkan nilai arah koefisien regresi. Selain itu juga dilihat nilai $\mathrm{t}$ hitung $>$ lebih 
besar dari $\mathrm{t}$ table $(2,939>1,960)$, sehingga dapat disimpulkan Price Earning Ratio (PER) berpengaruh signifikan terhadap return saham. Pada umumnya investor percaya bahwa perusahaan dengan PER yang tinggi berarti perusahaan tersebut mempunyai prospek pertumbuhan yang bagus, (Suparno 2002), dengan demikian perusahaan yang mempunyai PER yang tinggi akan menarik investor untuk membeli saham perusahaan tersebut. PER yang tinggi menunjukkan harga saham dinilai semakin tinggi oleh investor terhadap pendapatan perlembar sahamnya, sehingga PER yang semakin tinggi menunjukkan semakin mahal saham tersebut terhadap pendapatannya.

Debt to equity ratio (DER) memiliki pengaruh yang positif terhadap return saham perbankan. Ini terlihat dari nilai koefisien regresinya yang bernilai positif, yaitu sebesar 0,188. Ini berarti kenaikan DER akan menyebabkan naiknya return saham perbankan. Begitu pula sebaliknya ketika DER mengalami penurunan maka return saham juga akan turun, hal ini ditunjukkan nilai arah koefisien regresi. Debt to equity ratio (DER) berpengaruh signifikan terhadap return saham yg ditunjukkan nilai signifikan 0,001. Selain itu ditunjukkan dari nilai t hitung > lebih besar dari t table $(3,760>1,960)$. Penelitian ini sejalan dengan hasil penelitian Damodaran, 1997 (dalam Suparto, 2000). Debt to Equity Ratio (DER) akan mempengaruhi kinerja perusahaan dan menyebabkan apresiasi harga saham. DER yang tinggi diimbangi dengan penggunaaan hutang yg produktif dapat meningkatkan return saham dengan kata lain sepanjang penggunanan hutang mampu menaikkan return yang lebih besar dibandingkan dengan bunga yg akan dibayarkan oleh perusahaan yang bersangkutan maka penggunaan hutang masih layak dipertahankan.

Earning per share (EPS) berpengaruh positif terhadap return saham perbankan. Hal ini dapat dilihat dari nilai koefisien regresinya, sebesar 3,677 artinya bahwa kenaikan return Earning per share (EPS) dapat meningkatkan return saham perbankan begitu juga sebaliknya. PER berpengaruh positif dan signifikan terhadap return saham ditunjukkan nilai signifikan sebesar 0,000 atau thitung > t table $(2,287>1,960)$. Hal ini didukung penelitian Hanafi, dalam Arian Absari,D.Y.(2012).

Dari keempat variabel yang diuji, maka variabel yang lebih dominan mempengaruhi return saham adalah Earning Per sharer (EPS). Hal ini ditunjukkan dari nilai koefisien regressi sebesar 3,677. Hasil perhitungan menunjukkan bahwa nilai koefisien determinasi sebesar 52,5 $\%$ hal ini menunjukkan bahwa besarnya variasi return saham dapat dijelaskan variasi Likuiditas, PER, DER dan EPS sebesar 52,5\% 
sedangkan $47,5 \%$ dapat dijelaskan olek faktor lain yang tidak terliput dalam model penelitian ini, seperti fakor makroekonomi.

\section{Kesimpulan}

1. Likuiditas (LQ), Price Earning Ratio (PER), Debt to equity Ratio (DER), dan Earning Pershare (EPS) berpengaruh secara simultan dan signifikan terhadap return saham pada sektor perbankan Yang Go Publik di Bursa Efek Indonesia

2. Apakah Likuiditas (LQ), Price Earning Ratio (PER), Debt to equity Ratio (DER) , dan Earning Pershare (EPS) berpengaruh secara parsial dan signifikan terhadap return saham pada sektor perbankan Yang Go Publik di Bursa Efek Indonesia

3. Earning Pershare (EPS) mempunyai pengaruh yang dominan terhadap return saham pada sektor perbankan Yang Go Publik di Bursa Efek Indonesia

\section{Saran}

Dengan melihat hasil penelitian bahwa Likuiditas (LQ), Price Earning Ratio (PER),Debt to Equity ratio (DER), dan Earning Per Share (EPS) perlu dipertimbangkan untuk melakukan keputusan investasi .Faktor -faktor tersebut dapat digunakan untuk mengestimasi return saham perbankan yang go publik di Bursa Efek Indonesia.

\section{DAFTAR PUSTAKA}

Aristanto Eko, 2002. Pengaruh Faktor Fundamental Perusahaan dan Fundamental Ekonomi Terhadap Risiko Investasi Pada Saham Sektor Perbankan Yang Go Public Di Bursa Efek Jakarta Periode 1994-1999. Thesis Pascasarjana Universitas Padjadjaran bandung

Absari Dyatri Utami Arian, 2012. Analisis Pengaruh Faktor Fundamental Perusahaan Dan Risiko Sistematis Terhadap Return Saham Pada Perusahaan Manufaktur yang Listing Di Bursa Efek Indonesia Periode 2008-2011. Thesis Universitas Brawijaya Malang. http:// ejournal.uin-malang.ac.id/index.php/el.../article/.Di Akses 10 Desember 2019

Ang, Robert. 2001. Buku Pintar Pasar Modal Indonesia. Jakarta: Mediasoft. Indonesia

Bank Indonesia. Peraturan Bank Indonesia Nomor 16/11/PBI/2014 tentang Pengaturan dan Pengawasan Makroprudensial.

Brigham dan Houston. 2006. Dasar-Dasar Manajemen Keuangan. Edisi 
10. Jakarta: Salemba Empat.

Durham, JB. 2000. The Effect Of Monetary Policy On Montly And Quarterly Stock Market Return Cross-Country Evidence And Sensitivity Analyses, Working Paper, Divion Of Monetery Affairs Board Of Governors Of The Federal Reserve System, Washington DC.

Financial.bisnis.com Bisnis.com, JAKARTA 2015

Farkhan, Ika. 2013. Pengaruh Rasio Keuangan Terhadap Return Saham Perusahaan Manufaktur Di Bursa Efek Indonesia (Studi kasus Pada Perusahaan Manufaktur Sektor Food And Beverage) http://jurnal.unimus.ac.id Value Added, Vol. 9, No.1, September 2012 - Pebruari 2013 diakses 15 Agustus 2020

Hekinus Manao dan Deswin Nur, 2001. Assosiasi Rasio Keuangan dengan Retun Saham : Pertimbangan Ukuran Perusahaan serta Krisis Ekonomi di Indonesia. Simposium Akuntansi Nasional IV Ikatan Akuntan Indonesia, Departemen akuntan pendidik, 30-31 Agustus : 923-937

Husnan, S. 2005. Dasar-Dasar Teori Portfolio dan Analisis Sekuritas, Edisi Ketiga. Unit Penerbit dan Percetakan UNP YKPN. Yogyakarta.

IG.K.A.Ulupui.2009.Analisis pengaruh rasio likuiditas, laverage, aktivitas, dan profitabilitas terhadap return saham (study pada perusahaan makanan dan minuman dengan kategori industri barang dan konsumsi)Jurnal riset akuntansi dan bisnis. adhipranoto.wordpress.com

Jogiyanto H.M, 2000. Teori Portofolio dan Analisis Investasi Yogyakarta:BPFE

Meythi, 2006. Rasio Keuangan Yang Paling Baik Untuk Memprediksi Pertumbuhan Laba: Suatu Studi Empiris Pada Perusahaan Manufaktur Yang Terdaftar Di Bursa Efek Jakarta, Jurnal Ekonomi dan BisnisVol. XI No. 2, September

Noviandari, Widyastuti. 2007. Pengaruh Nilai TukarRupiah, Tingkat suku bunga Dan Inflasi TerhadapIndeks Harga Saham Sektor (IHSS) Keuangan

Di BEJ, Tesis, Program Magister ManajemenUniversitas Atma Jaya

Subalno, 2009. Analisis Pengaruh Faktor Fundamental dan Kondisi Ekonomi Terhadap Return Saham. Tesis. Universitas Diponegoro, Semarang. 
Sunardi, H. 2010. Pengaruh Penilaian Kinerja dengan ROI dan EVA terhadap Return Saham pada Perusahaan yang Tergabung dalam Indeks LQ 45 di Bursa Efek Indonesia, Jurnal Akuntansi hal: 70-92.

Suparno, 2002. Pengaruh Kinerja Keuangan terhadap Return Saham di Bursa Efek Jakarta (Studi kasus pada perusahaan Manufakture), Thesis Program Pasca sarjana: Program Magister Manajemen, universitas Padjadjaran , Bandung.

Sudarsono, Bambang; B. Sudiyatno, 2016. Faktor-faktor Yang Mempengaruhi Return Sahan Pada Perusahaan Properti dan Real Estate Yang Terdaftar Pada Bursa Efek Indonesia. Jurnal Bisnis dan Ekonomi (JBE), hal 1412-3126 Fakultas Ekonomi Universitas Stikubank Semarang

Sudiyatno, Bambang, Moch. Irsad, 2011. Menguji Model Tiga Faktor Fama Dan French Dalam Mempengaruhi Return Saham Studi Pada Saham Lq45 Di Bursa Efek Indonesia, Jurnal Bisnis dan Ekonomi, Vol. 18 No. 2

Syamsudin, L. 2007. Manajemen Keuangan Perusahaan, Edisi Baru. PT. Raja Grafindo Persada. Jakarta.

Tandelilin, E. 2010. Portofolio dan Investasi, Edisi Pertama. KANISIUS (Anggota IKAPI). Yogyakarta.

Usman, Bahtiar. 2003. Analisis Rasio Keuangan Dalam Memprediksi Perubahan Laba Pada Bank-bank di Indonesia. Media Riset Bisnis dan Manajemen, Vol.3, No.1, April, 2003, pp.59-74

Utami.M.dan Rahayu,M.,2003. Peranan Profitabilitas, SukuBunga, Infasi dan Nilai Tukar Dalam Mempengaruhi Pasar Modal Indonesia Selama Krisis Ekonomi. Jurnal Ekonomi Manajemen,Vol.5,No.2.

Wira, V. 2008. Analisa Karakteristik Perusahaan Terhadap Return dan Beta Perusahaan Makanan dan Minuman di Bursa Efek Jakarta, Jurnal Bisnis dan Manajeman hal : 1-110.

Wiksuana, I Gst. Bgs. 2008. Pengaruh Faktor-faktor Fundamental terhadap Return Saham di Bursa Efek Indonesia, Jurnal Bisnis dan Manajeman hal : 401-411. 